\section{Systematics of the Notostraca}

THe Notostraca constitute an order of the Euphyllopod Crustacea that is interesting not only because they are examples of primitive Crustacea but also because of their adaptation to life in temporary pools and practically world-wide distribution, and in "A Review of the Notostraca" (Bull. Brit. Mus. (Nat. Hist.), 3, No. 1 ; 1955. Pp. 57 ; 12s. 6d.) Alan R. Longhurst has carried out a detailed revision. Careful study of a large amount of material from different countries and museums and from popula. tions reared in the laboratory has shown that a number of the characters that have been used for the erection of species are, in fact, due to differences of age, sex and the number of body segments and appendages as well as the variations that occur naturally in large populations. Only two genera, Triops (Apus) and Lepidurus, are included in the family and order. Before this revision sixty-nine species and twelve varieties had been included in the order; but Longhurst has reduced that number to nine species and twelve varieties (not the same twelve as previously). The systematic part at the end includes a very clear and straightforward key for the identification of the species of the two genera, and in dealing with each species an indication of the range of variation is given and, where required, the differentiating characters of the varieties. For completeness, this section might have included the name of the family and its definition and definitions of the genera; for example, under Triops the only character given is that it is "separable from Lepidurus by its lack of a supra-anal plate".

\section{Measurement of High Temperatures by Thermo- couples of Noble Metals}

ThE accurate measurement of high temperatures is a matter of prime importance in many branches of science and technology, and, in particular, the greater control made possible by the use of thermocouples of noble metals has contributed materially to the successful development of improved methods in metallurgical industry and research. An interesting, illustrated survey of methods of high-temperature measurement and of the development of the thermocouple in this connexion is given in a new booklet, entitled "Noble Metal Thermocouples", by H. E. Bennett, which has been issued by Johnson, Matthey and Co., Ltd., of London (pp. 36 ; 1956). Three topics are dealt with separately : applications of the platinum metal thermocouple, with particular reference to its use in the steel industry; the properties of the platinum-group metals and their alloys; and the principal causes of deterioration of thermocouples under the headings of strain, prolonged heating at high temperatures, and contamination. Various physical properties of the platinum-group metals are listed, together with calibration curves for different kinds of platinum alloys/platinum thermocouples. Information is included of results of experiments conducted by the author, and there are many references to work of other investigators. A bibliography of forty-nine references is appended.

\section{British Standards Institution: Annual General} Meeting

AT the annual general meeting of the British Standards Institution on September 4, it was decided to combine the two formerly separate offices of president and of chairman of the General Council. Sir Herbert Manzoni (City Engineer of Birminghama), who is already chairman of Council, was elected the first president under this new arrangement. $\mathrm{He}$ succeeds Sir Roger Duncalfe, chairman of British Glues and Chemicals Ltd., who has served the Institution in many offices for the past twenty years. Mr. John Ryan (vice-chairman of the Metal Box Co., Ltd.) was re-elected vice-president. The following were elected, as representatives of the Institution's divisional councils, to serve on the General Council : Building Division: Mr. H. A. Pursey (Turners Asbestos Cement Co., Ltd.) ; Mr. J. C. Tait (Department of Health for Scotland); and Lieut.-Col. E. Vigor (Neuchatel Asphalte Co., Ltd.); Chemical Division: Mr. G. J. Cutbush (Metropolitan Leather Co., Ltd.); Mr. G. Dring (Bakelite, Ltd.); and Sir Knowles Edge (W. Edge and Sons, Ltd.) ; Engineering Division : Mr. P. L. Jones (Swan Hunter and Wigham Richardson, Ltd.) ; Mr. G. L. Newman (MetropolitanVickers Electrical Co., Ltd.); and Mr. B. E. A. Vigers (Laporte Industries, Ltd.); Textile Division : Mr. H. N. Aitken (British Celanese, Ltd.); Mr. L. F. Cockroft (John Cockroft and Sons, Ltd.); Mr. P. W. Gaddum (H. T. Gaddum and Co., Ltd.) ; and Mr. E. R. West (Jute Industries, Ltd.).

\section{National Smoke Abatement Society}

THE annual conference of the National Smoke Abatement Society will be held in Southport during October 3-5. The programme will include an address by Mr. Enoch Powell, Parliamentary Secretary to the Minister of Housing and Local Government, on the new Clean Air Act, and a session devoted to the Act from the point of view of local authorities. Other subjects to be discussed are the health aspects of the problem, pollution from road vehicles and problems of increasing the supply of solid smokeless fuels for use in smokeless zones and the new smoke control areas. The Des Voeux Memorial Lecture this year will be given by Sir Hugh Beaver, who will speak on "Clean Air : the Next Step". A resolution authorizing a special general meeting in the near future for the purpose of revising the Society's constitution and changing its name to the "National Clean Air Society" is to be considered. Further information can be obtained from the Society at Palace Chambers, Bridge Street, London, S.W.1.

\section{British Institution of Radio Engineers : Awards}

THE British Institution of Radio Engineers has recently awarded the following premiums for papers published in its Journal during 1955 : Clerk Maxwell Premium (the senior premium for the most outstanding paper in the Journal), to E. M. Bradley and Dr. D. H. Pringle (the theory and design of gas-discharge microwave attenuators); Heinrich Hertz Premium, to Dr. R. Filipowsky (electrical pulse communication systems) ; Louis Sterling Premium, to D. R. Coleman, D. Allanson and B. A. Horlock (the development and design of an underwater television camera); Marconi Premium, to Dr. Sin-Pih Fan (the magnetron beam-switching tube: its operation and circuit design criteria); and Leslie McMichael Premium, to D. J. Fewings and S. L. Fife (a survey of tuner designs for multi-channel television reception).

\section{Courtaulds' Scientific and Educational Trust Fund :}

Postgraduate Research Scholarships for 1956

THE Courtaulds' Scientific and Educational Trust Fund has recently announced the award of postgraduate research scholarships for 1956. Scholarships in a branch of science related to the textile, plastics 